\title{
Clinical Characteristics and Number of Valve Lesion in Rheumatic Heart Disease Severity
}

\author{
Saskia Ratna Desita, ${ }^{1}$ Achmad Lefi, ${ }^{2}$ Mahrus Rahman, ${ }^{3}$ Yudi Her Oktaviono ${ }^{2}$ \\ ${ }^{1}$ Medical Undergraduate Study Program, Faculty of Medicine, Universitas Airlangga, Surabaya, Indonesia, \\ ${ }^{2}$ Department of Cardiology and Vascular Medicine, Faculty of Medicine, Universitas Airlangga/Dr. Soetomo \\ Regional General Hospital, Surabaya, Indonesia, ${ }^{3}$ Department of Child Health, Faculty of Medicine, \\ Universitas Airlangga/Dr. Soetomo Regional General Hospital, Surabaya, Indonesia
}

\begin{abstract}
Rheumatic heart disease (RHD) occurs due to sequelae in the form of damage to the heart valves from the failure of acute rheumatic fever (ARF) therapy. Heart valve damage can cause various complications such as congestive heart failure, arrhythmias, pulmonary hypertension, atrial fibrillation, endocarditis, which can cause death. The study aimed to assess the association between clinical characteristics and valve lesion and rheumatic heart disease severity. The study was an analytic observational with a cross-sectional design of 73 patients with definite RHD from September 2019 to March 2020 in Dr. Soetomo Regional General Hospital. The majority of patients were female $(80 \%, p=0.235) 30-39$ years old $(34 \%, p=0.157)$. The mean age was $42.08 \pm 12.16$ years. The majority of patients have low socioeconomic status $(78 \%, \mathrm{p}=0.025)$ and rural dwelling location $(70 \%, \mathrm{p}=0.138)$ over three-quarters of patients living with more than four people in the same house (75\%). Multivalvular lesions (90\%, $\mathrm{p}=0.003)$ and severe RHD (77\%) were present predominantly. In conclusion, low socioeconomic status and multivalvular lesions are associated with rheumatic heart disease severity.
\end{abstract}

Key words: Clinical characteristic, rheumatic heart disease, severity, valve lesion

\section{Karakteristik Klinis dan Jumlah Lesi Katup pada Derajat Keparahan Penyakit Jantung Reumatik}

\begin{abstract}
Abstrak
Penyakit jantung reumatik (PJR) adalah penyakit yang terjadi akibat gejala sisa berupa kerusakan katup jantung dari kegagalan terapi demam reumatik akut (DRA). Kerusakan katup jantung pada PJR dapat menimbulkan berbagai komplikasi seperti gagal jantung kongesti, aritmia, hipertensi pulmonal, atrial fibrilasi, dan endokarditis yang dapat menyebabkan kematian. Penelitian ini bertujuan mencari hubungan karakteristik klinis dan jumlah lesi katup dengan derajat keparahan PJR. Penelitian ini merupakan analitik observasional menggunakan pendekatan cross-sectional. Sampel penelitian ini adalah pasien yang terdiagnosis definitif PJR berdasar atas ekokardiografi pada bulan Sepetember 2019-Maret 2020 di RSUD Dr. Soetomo Surabaya. Didapatkan 73 pasien sesuai dengan kriteria inklusi. Mayoritas pasien berjenis kelamin perempuan ( $80 \% ; \mathrm{p}=0,235)$, dengan kelompok usia 30-39 (34\%; $\mathrm{p}=0,157)$. Usia rerata 42,08 $\pm 12,16$ tahun. Sebagian besar pasien berstatus sosial ekonomi rendah $(78 \%, p=0,025)$ dan lokasi tinggal pedesaan $(70 \% ; p=0,138)$. Lebih dari tiga perempat pasien tinggal dengan $\leq 4$ orang di satu atap (75\%). Lesi multivalvular (90\%; $p=0,003$ ) dan PJR berat (77\%) ditemukan secara dominan. Simpulan, status sosial ekonomi rendah dan lesi katup multivalvular berhubungan dengan derajat keparahan penyakit jantung reumatik.
\end{abstract}

Kata kunci: Derajat keparahan, karakteristik klinis, lesi katup, penyakit jantung reumatik 


\section{Introduction}

Rheumatic heart disease (RHD) is heart valve damage due to the failure of acute rheumatic fever (ARF) therapy. ${ }^{1}$ ARF is an autoimmune disease caused by Group A Streptococcus (GAS) bacterial infection, characterized by clinical symptoms such as carditis, arthritis, syndrome's chorea, erythema marginatum, and subcutaneous nodule. Throat infections due to GAS in children and adolescents with a genetic predisposition that involve the nerves, skin, joints, and heart can cause ARF. ${ }^{2}$ Rheumatic heart disease was commonly affected in young-adult living with low socioeconomic status. ${ }^{3}$ and it latent in children and manifested clinically in adulthood. Individuals in countries affected by RHD are endemic late in the disease process and usually leave one or more ARF sequelae. Heart valve damage can cause various complications such as congestive heart failure, arrhythmias, pulmonary hypertension, atrial fibrillation, and endocarditis, which can cause death. ${ }^{4,5}$ According to WHO Global Health Estimates 2016, disability-adjusted life-years (DALYs) of RHD worldwide were 10,397,970; while it was 384,600 in Indonesia. ${ }^{6}$

RHD has several risk factors such as age, sex, socioeconomic status, occupancy density, nutritional status, prophylactic adherence, ignorance, genetic factors, and access to health facilities.7 Poverty was related to the severity of RHD in inpatients in sub-Saharan Africa. ${ }^{8}$ Age, sex, and area of origin were not associated with RHD severity. ${ }^{9}$ There are still few studies in Indonesia that assess the association between clinical characteristics and RHD severity. The author intends to prove the association between age, sex, area of origin, economic status with RHD severity. Moreover, to add the association between occupancy density and the number of valve lesions with RHD severity, so the medical personnel can know the management of RHD, determine appropriate prophylaxis, and anticipate the occurrence of more severe RHD.

\section{Methods}

The study was an analytic observational study with a cross-sectional design using questionnaires and medical records from September 2019 to March 2020 in Dr. Soetomo Regional General Hospital Surabaya. The sample was 73 patients with definite RHD based on World Heart Federation
(WHF) criteria in Dr. Soetomo Regional General Hospital Surabaya. Patients with standard echocardiography with clinical manifestation of RHD and non-RHD valvular heart disease were excluded.

The variables used in this study were dependent and independent. Dependent variables include age, sex, area of origin, economic status, occupancy density, and the number of valve lesions. The independent variable was RHD severity. Statistical analysis was to assess the association between dependent variables and independent variables. The data were analyzed using SPSS version 25 with the Fisher-FreemanHalton test.

Ethical clearance was approved by Health Research Ethics Committee Dr. Soetomo Regional General Hospital Surabaya with letter number 1512/KEPK/IX/2019.

\section{Results}

The patients are dominated by women (80\%), $30-39$ years $(34 \%)$, and living in a rural location (70\%). The economic status was defined by patients' monthly income and was divided into four categories based on the Statistics Indonesia which are Low ( $<$ IDR 1,500,000), middle (IDR 1,500,000-2,500,000), high (IDR $2,500,000-3,500,000$ ), and very high (more than IDR 3,500,000). The majority of patients have low economic status (78\%). Occupancy density is divided into two categories according to the number of people in one house, namely less than four people and more than four people. The results showed that $75 \%$ had an occupancy density of more than four people.

The number of patient valve lesions based on echocardiography was divided into two categories, univalvular and multivalvular lesions. The results showed that seven patients (10\%) had univalvular valve lesions, and 66 patients (90\%) had multivalvular valve lesions. RHD severity was divided into mild, moderate, and severe according to WHF 2012 echocardiography criteria. Data distribution obtained 3\% had mild RHD, 20\% moderate RHD, and 77\% severe RHD (Table 1).

Table 2 showed that the economic status and the number of valve lesion were associated with RHD severity ( $\mathrm{p}=0.025, \mathrm{p}=0.003$ ) whereas age, sex, area of origin, and occupancy density has no statistical difference. 
Table 1 Clinical Characteristics of Patients

\begin{tabular}{|c|c|c|}
\hline Characteristics & $n=73$ & Percentage \\
\hline \multicolumn{3}{|l|}{ Age (years) } \\
\hline$<20$ & 3 & 4 \\
\hline $20-29$ & 7 & 10 \\
\hline $30-39$ & 25 & 34 \\
\hline $40-49$ & 19 & 26 \\
\hline $50-59$ & 9 & 12 \\
\hline$\geq 60$ & 10 & 14 \\
\hline \multicolumn{3}{|l|}{ Sex } \\
\hline Male & 15 & 20 \\
\hline Female & 58 & 80 \\
\hline \multicolumn{3}{|l|}{ Area of origin } \\
\hline Urban & 22 & 30 \\
\hline Rural & 51 & 70 \\
\hline \multicolumn{3}{|l|}{ Economic status } \\
\hline Low $(<1,500,000$ IDR $)$ & 57 & 78 \\
\hline Middle $(1,500,000-2,500,000$ IDR $)$ & 5 & 7 \\
\hline High $(2,500,000-3,500,000$ IDR $)$ & 6 & 8 \\
\hline Very high (>3,500,00o IDR) & 5 & 7 \\
\hline \multicolumn{3}{|l|}{ Occupancy density } \\
\hline$>4$ people & 18 & 25 \\
\hline$\leq 4$ people & 55 & 75 \\
\hline \multicolumn{3}{|l|}{ The number of valve lesions } \\
\hline Univalvular & 7 & 10 \\
\hline Multivalvular & 66 & 90 \\
\hline \multicolumn{3}{|l|}{ RHD severity } \\
\hline Mild & 2 & 3 \\
\hline Moderate & 15 & 20 \\
\hline Severe & 56 & 77 \\
\hline
\end{tabular}

\section{Discussion}

The majority of patients were aged 30-39 years (34\%). A study in Papua's labor community who suffered RHD showed that nearly half of the sample was 35-44 years old..$^{10}$ According to Zhang et al., ${ }^{11}$ more than half of patients with RHD were in the aged group 20-39. $61 \%$ of patients with ARF developed into RHD after ten years. ${ }^{12}$ RHD peaked in the third and fourth decades. ${ }^{13,14}$

The results showed that age has no statistical difference with RHD severity $(p=0.157)$. The development of ARF into RHD for each individual varies from several years to more than 20 years. ${ }^{15}$ RHD is initially asymptomatic, as well as ignorance and difficulty accessing health facilities that cause patients to experience delays in initial diagnosis.

Female was present predominantly in this study (80\%). Females are more susceptible to developing autoimmune reactions after being infected with GAS. Social factors such as involvement in raising children and access to health services also lead to increased vulnerability and the possibility of GAS infection. ${ }^{14}$ Females tend to have more severe aortic valve lesions compared to males. ${ }^{16}$ Statistical analysis showed that sex was not associated with RHD severity ( $p=0.235$ ). According to Lubega et al. ${ }^{17}$ there is no association between sex and tricuspid regurgitation, mitral stenosis severity. There still many factors to considered, such as prophylactic compliance, access to health care, and adherence for RHD. ${ }^{7}$

RHD mostly takes place in rural areas. ${ }^{18,19}$ This study showed that $70 \%$ of patients were living in rural areas. Rural areas tend to have insufficient clean water facilities and environmental 
Table 2 Clinical Characteristics and Valve Lesion in Rheumatic Heart Disease Severity

\begin{tabular}{|c|c|c|c|c|}
\hline \multirow[t]{2}{*}{ Characteristics } & \multicolumn{3}{|c|}{$\begin{array}{l}\text { Rheumatic Heart Disease Severity } \\
((n=73)\end{array}$} & \multirow{2}{*}{$\mathbf{p}$} \\
\hline & Mild & Moderate & Severe & \\
\hline Age (years) & & & & 0.157 \\
\hline$<20$ & o & 1 & 2 & \\
\hline $20-29$ & 1 & 1 & 5 & \\
\hline $30-39$ & 1 & 4 & 20 & \\
\hline $40-49$ & o & 2 & 17 & \\
\hline $50-59$ & o & 5 & 4 & \\
\hline$\geq 60$ & o & 2 & 8 & \\
\hline Sex & & & & 0.235 \\
\hline Male & o & 1 & 14 & \\
\hline Female & 2 & 14 & 42 & \\
\hline Area of origin & & & & 0.138 \\
\hline Urban & o & 11 & 40 & \\
\hline Rural & 2 & 4 & 16 & \\
\hline Economic status & & & & 0.025 \\
\hline Low $(<1,500,000$ IDR $)$ & o & 11 & 46 & \\
\hline Middle $(1,500,000-2,500,000$ IDR $)$ & 1 & 0 & 4 & \\
\hline $\operatorname{High}(2,500,000-3,500,000$ IDR $)$ & o & 2 & 4 & \\
\hline Very high $(>3,500,000$ IDR $)$ & 1 & 2 & 2 & \\
\hline Occupancy density & & & & 0.065 \\
\hline$>4$ people & 2 & 4 & 12 & \\
\hline$\leq 4$ people & o & 11 & 44 & \\
\hline The number of valve lesions & & & & 0.003 \\
\hline Univalvular & 2 & 2 & 3 & \\
\hline Multivalvular & $\mathrm{o}$ & 13 & 53 & \\
\hline
\end{tabular}

conditions, affecting the risk of RHD. ${ }^{20}$ The results showed that the original area has no statistical significance in RHD severity $(\mathrm{p}=0.135)$. Other parameters, for instance, access to healthcare facilities and prophylaxis adherence, need to be measured..$^{21,22}$ According to Melani, ${ }^{9}$ the area of origin has no association with RHD severity. It is stated that patients who come from outside the city of Medan have difficulty accessing complete health services to enter the Adam Malik General Hospital in a severe condition.

Low economic status was associated with RHD severity $(\mathrm{p}=0.025)$. The majority of patients have low economic status. RHD mostly occurs in developing countries with low socioeconomic status. ${ }^{23}$ Monthly income was associated with RHD risk. ${ }^{24}$ Low economic status is tied to living conditions and lack of access to health services. ${ }^{20}$

Occupancy density was not associated with RHD severity ( $p=0.065)$. The results showed that $75 \%$ of patients living with more or four people in the same house. Some parameters must be measured: house area, area per person, number of siblings, number of beds, and number of people in one room. ${ }^{25}$

Statistical analysis showed that multivalvular lesions were associated with more severe RHD $(\mathrm{p}=\mathrm{0.003})$. Heart valve lesions are progressive and cause various complications such as congestive heart failure, arrhythmia, stroke, atrial fibrillation, endocarditis, and death. 4,5 Initially, RHD showed no symptoms, causing the patient to be late for echocardiography screening. The difficulty in getting to health facilities in developing countries, and the fact that Dr. Soetomo is a type A referral hospital where most patients are already in multivalvular valve lesions.

\section{Conclusions}

Rheumatic heart disease (RHD) patients' clinical characteristics at Dr. Soetomo Regional General 
Hospital Surabaya were on 30-39 years age group, female, living in rural area, having low economic status, and living with four people or more on the same roof. The majority of RHD patients had multivalve and severe RHD. Low economic status and multivalvular lesions were associated with RHD severity.

\section{Conflict of Interest}

There is no conflict of interest.

\section{Acknowledgments}

Researchers wish to thank the Department of Cardiology and Vascular Medicine, Faculty of Medicine Universitas Airlangga/Dr. Soetomo Regional General Hospital Surabaya, for help and support.

\section{References}

1. Hasnul M, Najirman, Yanwirasti Y. Karakteristik pasien penyakit jantung rematik yang dirawat inap di RSUP Dr. M. Djamil Padang. JKA. 2015;4(3):894-900.

2. Guilherme L, Sampaio RO, Freschi de Barros S, Köhler KF, Spina GS, Tarasoutchi F, et al. Rheumatic fever and rheumatic heart disease. In: Nussinovitch U, editor. The heart in rheumatic, autoimmune and inflammatory diseases: pathophysiology, clinical aspects and therapeutic approaches. London: Academic Press; 2017. p. 529-51.

3. Nulu S, Bukhman G, Kwan GF. Rheumatic heart disease: the unfinished global agenda. Cardiol Clin. 2017;35(1):165-80.

4. Zühlke L, Engel ME, Karthikeyan G, Rangarajan S, Mackie P, Cupido B, et al. Characteristics, complications, and gaps in evidence-based interventions in rheumatic heart disease: the Global Rheumatic Heart Disease Registry (the REMEDY study). Eur Heart J. 2015;36(18):1115-22.

5. Okello E, Wanzhu Z, Musoke C, Twalib A, Kakande B, Lwabi P, et al. Cardiovascular complications in newly diagnosed rheumatic heart disease patients at Mulago Hospital, Uganda. Cardiovasc J Afr. 2013;24(3):80-5.

6. World Health Organization. Global health estimates 2016 summary tables: globals by cause, age and sex, 2000-2016 [Internet]. Geneva: World Health Organization;
2016 [cited 2020 April 26]. Available from: https://www.who.int/healthinfo/ global_burden_disease/GHE2016_DALY_ Global_2000_2016_.xls.

7. Okello E, Kakande B, Sebatta E, Kayima J, Kuteesa M, Mutatina B, et al. Socioeconomic and environmental risk factors among rheumatic heart disease patients in Uganda. PLoS ONE. 2012;7(8):e43917.

8. Kingué $\mathrm{S}, \mathrm{Ba} \mathrm{SA}$, Balde $\mathrm{D}$, Diarra $\mathrm{MB}$, Anzouan-Kacou JB, Anisubia B, et al. The VALVAFRIC study: a registry of rheumatic heart disease in Western and Central Africa. Arch Cardiovasc Dis. 2016;109(5):321-9.

9. Melani TA. Karakteristik penderita penyakit jantung rematik (PJR) yang dirawat inap di RSUP H. Adam Malik Medan tahun 2004-2008 [undergraduate thesis]. Medan: Universitas Sumatera Utara; 2010 [cited 2020 April 26]. Available from: https://repository. usu.ac.id/handle/123456789/14616.

10. Rodriguez-Fernandez R, Amiya R, Wyber R, Widdodow W, Carapetis J. Rheumatic heart disease among adults in a mining community of Papua, Indonesia: findings from an occupational cohort. Heart Asia. 2015;7(2):44-8.

11. Zhang W, Mondo C, Okello E, Musoke C, Kakande B, Nyakoojo W, et al. Presenting features of newly diagnosed rheumatic heart disease patients in Mulago Hospital: a pilot study. Cardiovasc J Afr. 2013;24(2):28-33.

12. Lawrence JG, Carapetis JR, Griffiths K, Edwards K, Condon JR. Acute rheumatic fever and rheumatic heart disease: incidence and progression in the Northern Territory of Australia, 1997 to 2010. Circulation. 2013;128(5):492-501.

13. Sika-Paotonu D, Beaton A, Carapetis J. Epidemiology and global burden of rheumatic heart disease. In: Camm AJ, Lüscher TF, Maurer G, Serruys PW, editors. The ESC textbook of cardiovascular medicine. 3rd Edition. Oxford: Oxford University Press; 2018. p. 314-22.

14. Carapetis JR, Beaton A, Cunningham MW, Guilherme L, Karthikeyan G, Mayosi BM, et al. Acute rheumatic fever and rheumatic heart disease. Nat Rev Dis Primers. 2016;2:15084.

15. Laudari S, Subramanyam G. A study of spectrum of rheumatic heart disease in a tertiary care hospital in Central Nepal. Int $J$ Cardiol Heart Vasc. 2017;15:26-30. 
16. Xiao F, Zheng R, Yang D, Cao K, Zhang S, Wu $\mathrm{B}$, et al. Sex-dependent aortic valve pathology in patients with rheumatic heart disease. PLoS ONE. 2017;12(6):eo180230.

17. Lubega S, AlikuT, Lwabi P.Echocardiographic pattern and severity of valve dysfunction in children with rheumatic heart disease seen at Uganda Heart Institute, Mulago hospital. Afr Health Sci. 2014;14(3):617-25.

18. ZühlkeL, BeatonA, EngelME, Hugo-Hamman CT, Karthikeyan G, Katzenellenbogen J, et al. Group A streptococcus, acute rheumatic fever and rheumatic heart disease: epidemiology and clinical considerations. Curr Treat Options Cardiovasc Med. 2017;19(2):15.

19. Sriharibabu M, Himabindu Y, Kabir Z. Rheumatic heart disease in rural south India: a clinico-observational study. J Cardiovasc Dis Res. 2013;4(1):25-9.

20. Sharma N, Toor D. Impact of socio-economic factors on increased risk and progression of rheumatic heart disease in developing nations. Curr Infect Dis Rep. 2019;21(6):21.

21. Islam AKMM, Majumder AAS. Rheumatic fever and rheumatic heart disease in Bangladesh: a review. Indian Heart J. 2016;68(1):88-98.

22. Camara EJN, Santos JM Dos, Alves-Silva LS, Latado AL. Rheumatic fever recurrence: risk factors and clinical characteristics. Clin Trials Regul Sci Cardiol. 2016;19:5-8.

23. Beg A, Younas M, Touseef A. Rheumatic heart disease (RHD); socio-economic and environmental risk factors for acute rheumatic fever (ARF) and rheumatic heart disease (RHD) patients in Pakistan. TPMJ. 2016;23:324-7.

24. Baro L, Sharma N, Toor D, Chaliha MS, Kusre G, Baruah SM, et al. A hospital-based study of socioeconomic status and clinical spectrum of rheumatic heart disease patients of Assam, North-East India. Eur J Prev Cardiol. 2018;25(12):1303-6.

25. Riaz BK, Selim S, Karim MN, Chowdhury KN, Chowdhury SH, Rahman MR. Risk factors of rheumatic heart disease in Bangladesh: a case-control study. J Health Popul Nutr. 2013;31(1):70-7. 